\title{
EVALUATION OF POSTOPERATIVE PAIN AFTER USING DIFFERENT FILE SYSTEMS: A RANDOMIZED CLINICAL STUDY
}

\section{ABSTRACT}

Objectives: This study evaluated the effect of instrumentation techniques on the postoperative pain after single-visit root canal treatment.

Materials and Methods: Sixty patients having an indication of endodontic treatment were included. Only single rooted teeth were selected The patients were randomly divided into 2 groups. In group 1; the root canals were instrumented using ProTaper Next instruments with rotational motion, in group 2 TF Adaptive instruments with adaptive motion were used during instrumentation. Treatments were completed in a single appointment. Postoperative pain questionnaires were scored by patients using a four-point pain intensity scale for 12, 24, and 48 hours. Mann Whitney-U, Friedman and Wilcoxon tests were used for analyzing the final data.

Results: The comparison of time intervals between groups demonstrated no difference between both groups ( $p>0.05$ ). In both groups, the postoperative pain values of $12 \mathrm{~h}$ time period were significantly higher than both other periods, and significant difference was found between $24 \mathrm{~h}$ and $48 \mathrm{~h}$ time periods $(\mathrm{p}<0.05)$. The postoperative pain values of $48 \mathrm{~h}$ time period were significantly lower than the other two time periods $(\mathrm{p}<0.05)$.

Conclusions: Both instrumentation techniques caused postoperative pain. The pain scores indicated that both techniques caused limited discomfort associated with slight pain which did not require any additional treatment and medication.

Keywords: Pain, root canal preparation, root canal treatment.

\author{
(D) Olcay Özdemir ${ }^{1}$ \\ (iD) Ecehan Hazar ${ }^{1}$ \\ (D) Mustafa Murat Koçak ${ }^{1}$ \\ (ID) Sibel Koçak ${ }^{1}$ \\ (ID)* Baran Can Sağlam ${ }^{1}$
}

ORCID IDs of the authors: O.Ö.0000-0001-8867-1551 E.H.0000-0002-7610-9622 M.M.K.0000-0003-3881-589X S.K.0000-0003-2354-7108 B.C.S.0000-0002-2090-5304

${ }^{1}$ Department of Endodontics, Faculty of Dentistry, Zonguldak Bülent Ecevit University, Zonguldak, Turkey

$\begin{array}{ll}\text { Received } & : 15.05 .2019 \\ \text { Accepted } & : 24.06 .2019\end{array}$




\section{INTRODUCTION}

Postoperative pain is a common complication after root canal treatment. The reasons for such pain may include apical debris extrusion, inadequate preparation, preoperative pain, and the presence of periapical pathology. ${ }^{1-3}$ Apical debris extrusion affects the postoperative comfort of patients without any significant impact on the outcome of treatment. ${ }^{4}$

Root canal shaping kinematics and file design can affect the amount of extruded debris. ${ }^{5}$ Recently, endodontic motors using combined motions, instead of rotational and reciprocal motions solely, were used to reduce the complications that may occur during treatment. However, these new instruments and movements tend to create more debridement. ${ }^{6}$

ProTaper Next (Dentsply Maillefer, Ballaigues, Switzerland) instruments have an asymmetric rectangular cross section and were manufactured from M-WIRE nickel-titanium (NiTi) alloy. The files operate with a rotational movement that makes a snakelike motion during preparation. The rotation of the asymmetric section creates a larger area for the transportation of debris. $^{7,8}$ Twisted-File (TF) Adaptive (Kerr Endodontics, Orange, CA, USA) instruments accommodates torsional force in the canal by performing rotational or reciprocal movements depending on the pressure on the file. The adaptive movement provides less compression on file. ${ }^{9}$

Limited information is available comparing the effects of TF Adaptive and ProTaper Next systems on postoperative pain formation. Thus, the aim of this study is to compare the severity of postoperative pain following root canal treatment by using rotational and adaptive techniques. Our hypothesis is that different techniques affect the severity of postoperative pain.

\section{MATERIALS AND METHODS}

The plan of the study was registered at www.clinicaltrial.gov (ClinicalTrials.gov Identifier NCT number: NCT03708081). This study was accomplished under the standing orders of the ethics committee (protocol number: 201798-20/09). Patients having teeth with asymptomatic irreversible pulpitis or pulp necrosis, who referred to Faculty of Dentistry, Department of Endodontics were included. Only single rooted teeth were selected. The patients with sinus tract, periradiculer abscess or facial cellulitis, who had previously taken any medication, and who had previously undergone root canal treatment with the related tooth were excluded. After the detailed written medical and dental history were obtained, the written consent form was taken from the patients who wanted to participate in the study. The patients having any systemic disease or any medication related to a systemic condition were excluded. Age, gender, and the location of teeth were recorded. Incisors and canine teeth having single root and canal were included. An electric pulp test (Elements pulp vitality tester, SybronEndo, Orange, CA, USA) was applied to determine the vitality of the teeth. An initial pilot study was conducted on overall 30 patients (15 individuals per group). The power analysis, performed for the pilot study, indicated that a minimum of number of 28 patients was required for each group to identificate significant differences. Therefore, 30 patients were included for each group to ensure a significative exemplary.

Overall, 60 patients were included. The ages of participants ranged between 18 and 63 years. For the elimination or limitation of any variables, a single operator completed all treatment procedures. After the teeth were isolated and the access cavities were prepared, the working length was determined by an electronic apex finder (Root ZX mini; J. Morita, Tokyo, Japan).

Patients were randomly divided 2 groups as follows;

In group 1, the root canals were instrumented using ProTaper Next files with a full sequence of X1 to X5 (50/.06), respectively.

In group 2, instrumentation was performed with TF Adaptive ML1, ML2, ML3 (50/.04) instruments. An adaptive motion was expected for each specimen during instrumentation. In case of lacking of any adaptive motion occurrence, the specimen was excluded. A total of 4 specimens was excluded due to this reason. 
During the instrumentation, the root canals were irrigated with a total of $10 \mathrm{ml}$ of $2.5 \%$ sodium hypochloride. Final irrigation was performed with $5 \mathrm{ml}$ of $2.5 \%$ sodium hypochloride, $5 \mathrm{ml}$ of $17 \%$ Ethylenediaminetetraacetic acid, $5 \mathrm{ml}$ of $2 \%$ chlorhexidine. $5 \mathrm{ml}$ of distilled water was applied after each solution to prevent any reaction that might occur between the solutions.

The root canals were obturated with cold lateral compaction method using matched guttapercha cones and resin-based canal sealer (Adseal, Meta Biomed, Korea), and the quality of obturation was confirmed with radiographs. Finally, the access cavity was sealed with composite resin (Estelite $\Sigma$ Quick, Tokuyama Dental Corp. Tokyo, Japan), and the occlusion was checked.

Postoperative pain questionnaires were scored by patients using a four-point pain intensity scale for 12,24 , and 48 hours. ${ }^{10}$ The pain scores were as follows;

1- no pain;
2- mild pain (slight discomfort, no treatment required);

3- moderate pain (pain relieved by medication);

4- severe pain (pain and/or swelling not relieved by simple analgesic medication and the requirement of an unscheduled appointment). All scores were processed on the patient's treatment charts and statistical analysis of the results was performed after the planned number of patients had been treated.

The statistical analysis of the data was performed with SPSS 19.0 software. MannWhitney U test was used to compare between groups for each time period. Friedman test followed by Wilcoxon signed rank test used for the comparison of time periods in each group. The significance level was set at $\mathrm{p}<0.05$.

\section{RESULTS}

The mean, standard deviations, minimum and maximum values of two groups, including time periods were presented in Table 1.

Table 1 Mean pain scores, standart deviations, and minimum and maximum values

\begin{tabular}{|c|c|c|c|c|c|}
\hline Groups & Time & Mean & Standart deviation & Minimum & Maximum \\
\hline \multirow[t]{3}{*}{ PTX } & $12 \mathrm{~h}$ & 1.63 & .890 & 1 & 4 \\
\hline & $24 \mathrm{~h}$ & 1.43 & .728 & 1 & 3 \\
\hline & $48 \mathrm{~h}$ & 1.20 & .484 & 1 & 2 \\
\hline \multirow[t]{3}{*}{ TFA } & $12 \mathrm{~h}$ & 1.50 & .731 & 1 & 4 \\
\hline & $24 \mathrm{~h}$ & 1.23 & .430 & 1 & 2 \\
\hline & $48 \mathrm{~h}$ & 1.10 & .305 & 1 & 2 \\
\hline
\end{tabular}

Severe pain was only recorded in 12 hours period, whilst the 48 time period did not demonstrate any moderate or severe pain scores for both groups. The comparison of time intervals between groups demonstrated no difference between both groups $(\mathrm{p}>0.05)$. The total number of patients experiencing pain for both groups in 12, 24, and 48 hours were recorded as 16,11 , and 9 , respectively. In both groups, the highest postoperative pain values were found in $12 \mathrm{~h}$ time periods. In both groups, the postoperative pain values of $12 \mathrm{~h}$ time period were significantly higher than both other periods, and significant difference was found between $24 \mathrm{~h}$ and $48 \mathrm{~h}$ time periods $(\mathrm{p}<0.05)$. The postoperative pain values of $48 \mathrm{~h}$ time period were significantly lower than the other two time periods $(p<0.05)$. No differences were found between female and male patients, similarly, between maxilla and mandibula ( $>0.05)$ (Table 2). The demographic features were presented in Table 3. 
Table 2. Mean pain scores according to gender and localization

\begin{tabular}{llll}
\hline \multirow{2}{*}{$\begin{array}{l}\text { Gender of patient/ Location of } \\
\text { tooth }\end{array}$} & $\mathbf{1 2 h}$ & $\mathbf{2 4 h}$ & $\mathbf{4 8 h}$ \\
\cline { 2 - 4 } Female $(\mathrm{n}=24)$ & $\mathbf{M e a n}($ Std Dev.) & & \\
\hline Male $(\mathrm{n}=36)$ & $1.54(.884)$ & $1.38(.711)$ & $1.21(.509)$ \\
Mandibular $(\mathrm{n}=29)$ & $1.28(.701)$ & $1.28(.615)$ & $1.14(.424)$ \\
Maxillary $(\mathrm{n}=31)$ & $1.41(.780)$ & $1.31(.604)$ & $1.17(.468)$ \\
\hline
\end{tabular}

Table 3. The demographic features of individuals

\begin{tabular}{llll}
\hline Demographic features & & $\begin{array}{l}\text { ProTaper Next } \\
(\mathbf{n = 3 0})\end{array}$ & $\begin{array}{l}\text { TF Adaptive } \\
(\mathbf{n = 3 0 )}\end{array}$ \\
\hline \multirow{2}{*}{ Gender } & Female & $35 \%$ & $40 \%$ \\
& Male & $65 \%$ & $60 \%$ \\
\multirow{2}{*}{ Age } & Mean & 39.65 & 31.75 \\
& Range & $19-63$ & $18-59$ \\
Localization & Maxilla & 15 & 16 \\
& Mandibula & 15 & 14 \\
\hline
\end{tabular}

\section{DISCUSSION}

The aim of this clinical study was to compare the intensity and duration of postoperative pain after single-visit root canal treatment with rotational and adaptive motions. In general, patients and clinicians prefer single-visit treatments due to their advantages such as low cost, fewer operative procedures, elimination of interappointment leakage and less chair time. ${ }^{11,12}$ Therefore, a single visit treatment was selected for all patients. Additionally, final apical file diameter, type and amount of irrigation solution, obturation method were standardized to eliminate any bias in both groups.

Various scales were used to evaluate the severity of postoperative pain after root canal treatment. In this study, a four-point pain intensity scale, which was considered to be an adequate and reliable method, was used. ${ }^{13}$ This scale method was also used in various recent studies for measuring the severity of postoperative pain after root canal treatment. ${ }^{1,13,14}$ Different time intervals can be selected to evaluate the intensity of pain. The evaluation of postoperative pain was performed for different time periods in recent studies. Comparin et al. ${ }^{15}$ and Gambarini et al. ${ }^{16}$ evaluated the first 72 hours, whereas the first 120 hours was selected by Yaylali et al. ${ }^{17}$ after treatment. In the present study, the postoperative pain was evaluated in three different time intervals. The prevalence and severity of pain after root canal treatment decreases after the first 48 hours. ${ }^{18}$ Therefore, 12, 24, and 48 hours were selected similar to previous clinical studies. ${ }^{1,19,20}$ The highest postoperative pain values were recorded at $12 \mathrm{~h}$ period in both groups. No increase in pain scores was recorded as time progresses, similar to previous clinical studies. ${ }^{1,20}$ An unscheduled appointment for emergency treatment of acute apical abscess formation was recorded for only 1 patient. The associated tooth was directed for the extraction due to the patient's request and excluded from the study. Other than this patient, no symptoms such as postoperative swelling or paresthesia were recorded.

Various factors, such as age, gender, pulpal and periapical condition, type of tooth, preoperative pain, and technical characteristics, may affect postoperative pain. ${ }^{22}$ In the present study, gender did not affect the incidence of postoperative pain, despite the female patients demonstrated slightly higher scores for all time intervals in accordance with other studies. ${ }^{13,22}$ Additionally, the location of the tooth was not found to be a determinant on the pain scores, since no difference was found between mandibular and maxillary teeth. Besides, asymptomatic teeth were included to eliminate a possible preoperative variation. The relationship between age and 
postoperative pain demonstrated contradictory results. In the present study, no difference was found in terms of age between groups similar to previous studies. ${ }^{23,24}$ However, Azim et al. ${ }^{25}$ reported higher risk for the patients $>50$ years in developing flare-ups.

Various instruments and instrumentation techniques are available in the market for clinicians to use in daily endodontic practice. All instruments and techniques may be related to postoperative pain. Several studies compared ProTaper Next system with other instruments and techniques. ProTaper Next demonstrated similar results with various reciprocal instruments in regard to the incidence of postoperative pain., ${ }^{1,26}$ However, limited data are available for the TF Adaptive system and adaptive motion in terms of postoperative pain occurrence. Similar to ProTaper Next system, TF Adaptive resulted in significantly less incidence of severe pain symptoms than reciprocal technique. ${ }^{27}$ Çiçek et al. ${ }^{1}$ reported less postoperative pain with modified step-back technique than rotational and reciprocal technique. However, no difference was reported between the rotation and reciprocation techniques. The results of the present clinical trial also corroborate the clinical findings of Relvas et al..$^{28}$ who reported low and similar occurrence of postoperative pain between the reciprocating and rotary techniques. According to the present results, the null hypothesis was rejected. The ProTaper Next instruments demonstrated higher pain scores compared to the TF Adaptive system without any significance. The occurrence of adaptive motion, including rotational and reciprocal movements may lead to prevent the movement of debris to apical direction. Other possibilities related to this finding could be higher taper of the files which may result in the occurrence of more debris, and the requirement of more files to complete the instrumentation in ProTaper Next system during the root canal shaping procedures.

\section{CONCLUSIONS}

Both instrumentation techniques caused postoperative pain. The pain scores indicated that both techniques caused limited discomfort associated with slight pain which did not require any additional treatment and medication.

\section{ACKNOWLEDGEMENTS}

None

\section{CONFLICT OF INTEREST STATEMENT}

None

\section{Farklı Ĕge Sistemlerinin Kullanımı Sonrası Oluşan Postoperatif Ağrının Değerlendirilmesi: Randomize Klinik Çalışma}

$\ddot{O} Z$

Amaç: Bu çalışmada enstrümantasyon tekniklerinin tek seans kanal tedavisi sonrast postoperatif ağrl üzerine etkileri değerlendirilmiştir. Gereç ve Yöntemler: Çalışmaya endodontik tedavi endikasyonu olan 60 hasta dahil edildi. Sadece tek köklü dişler seçildi. Hastalar rastgele iki gruba ayrldı. Grup l'de kök kanallar rotasyonal hareket ile ProTaper Next enstrümanlart kullanılarak, grup 2'de TF Adaptive enstrümanlar adaptif hareket ile kullanılarak genişletildi. Tedaviler tek bir randevuda tamamlandl. İslem sonrası ağrl, 4 nokta ăgrt şiddet skalast ile 12, 24 ve 48. saatler için hastalar tarafindan işaretlendi. Verilerin analizi için Mann Whitney-U, Friedman ve Wilcoxon testleri kullanild. Bulgular: Zaman arallklarina göre preparasyon tekniklerinin karşılaştırılmasında fark bulunamadl $(p>0,05)$. Her iki grupta da 12. saatteki ağrl değerleri diğer iki periyottan anlaml olarak yüksek bulundu ve ayrica 24 ve 48 . saat arasinda fark tespit edildi $(p<0,05)$. 48. saat değerleri anlaml olarak diğgr iki saatten daha düşük bulundu $(p<0,05)$. Sonuç: Her iki enstrümantasyon tekniği işlem sonrası ă̆riya neden olmuştur. Her iki teknik, ilave bir tedavi veya ilaç uygulaması gerektirmeyen sinurl rahatsizllk ve hafif ağrl skorları göstermişstir. Anahtar Kelimeler: A $\breve{g r l}$, kök kanalını hazırlama, kök kanal tedavisi.

\section{REFERENCES}

1. Cicek E, Koçak MM, Koçak S, Sağlam BC, Türker SA. Postoperative pain intensity after using different instrumentation techniques: a randomized clinical study. J Appl Oral Sci 2017;25:20-26.

2. Alves Vde O. Endodontic flare-ups: a prospective study. Oral Surg Oral Med Oral Pathol Oral Radiol Endod 2010;110:68-72.

3. Sathorn C, Parashos P, Messer H. The prevalence of postoperative pain and flare-up in single- and multiple- 
visit endodontic treatment: a systematic rewiew. Int Endod J 2008;41:191-196.

4. Bürklein S, Schäfer E. Apically extruded debris with reciprocating single and full-sequence rotary instrumentation systems. J Endod 2012;38:850-852.

5. Caviedes- Bucheli J, Castellanos F, Vasquez N, Ulate E, Munoz HR. The influence of two reciprocating single-file and two rotary-file systems on the apical extrusion of debris and its biological relationship with symptomatic apical extrusion of debris and its biological relationship with symptomatic apical periodontitis. A systematic review and meta-analysis. Int Endod J 2016;49:255-270.

6. Kim HC, Kwak SW, Cheung GS, Ko DH, Chung SM, Lee W. Cyclic fatigue and torsional resistance of two new nickel-titanium instruments used in reciprocation motion: Reciproc versus WaveOne. J Endod 2012;38:541-544.

7. Bürklein S, Mayhey D, Schäfer E. Shaping ability of Protaper NEXT and BT-RaCe nickel-titanium instruments in severely curved root canals. Int Endod J 2015;48:774-781.

8. Koçak MM, Çicek E, Koçak S, Sağlam BC, Yılmaz N. Apical extrusion of debris using Protaper Universal and Protaper Next rotary systems. Int Endod J 2015;48:283-289.

9. Akbulut MB, Akman M, Terlemez A, Magat G, Sener S, Shetty H. Efficacy of Twisted file Adaptive, Resiproc and Protaper Universal Retreatment instruments for root-canal-filling removal: A cone-beam computed tomography study. Dent Mater J 2016;35:126-131.

10. McCrirrick A, Hunter S. Pain on injection of propofol: the effect of injectate temperature. Anaesthesia 1990;45:443-444.

11. Sue Y, Wang C, Ye L. Healing rate and postobturation pain of single- versus multiple-visit endodontic treatment for infected root canals: a systematic review. J Endod 2011;37:125-132.

12. Pak JG, White SN. Pain prevalence and severity before, during, and after root canal treatment: a systematic review. J Endod 2011;37:429-438.

13. El Mubarak AH, Abu-bakr NH, Ibrahim YE. Postoperative pain in multiple-visit and single-visit root canal treatment. J Endod 2010;36:36-39.

14. Menhinick KA, Gutmann JL, Regan JD, Taylor SE, Buschang PH. The efficacy of pain control following nonsurgical root canal treatment using ibuprofen or a combination of ibuprofen and acetaminophen in a randomized, double-blind, placebo-controlled study. Int Endod J 2004;37:531-541.

15. Comparin D, Moreira EJL, Souza EM, De-Deus G, Arias A, Silva EJNL. Postoperative Pain after Endodontic Retreatment Using Rotary or Reciprocating Instruments: A Randomized Clinical Trial. J Endod 2017;43:1084-1088.

16. Gambarini G, Di Nardo D, Miccoli G, Guerra F, Di Giorgio G, Glassman G, Piasecki L, Testarelli L. The Influence of a New Clinical Motion for Endodontic Instruments on the Incidence of Postoperative Pain. Clin Ter 2017;168:23-27.

17. Yaylali IE, Kurnaz S, Tunca YM. Maintaining Apical Patency Does Not Increase Postoperative Pain in Molars with Necrotic Pulp and Apical Periodontitis: A Randomized Controlled Trial. J Endod 2018;44:335340.

18. Seltzer S. Pain in endodontics. 1986. J Endod 2004; 30:501-503.

19. Ramamoorthi S, Nivedhitha MS, Divyanand MJ. Comparative evaluation of postoperative pain after using endodontic needle and EndoActivator during root canal irrigation: A randomised controlled trial. Aust Endod J 2015;41:78-87.

20. Silva EJ, Menaged K, Ajuz N, Monteiro MR, Coutinho-Filho Tde S. Postoperative pain after foraminal enlargement in anterior teeth with necrosis and apical periodontitis: a prospective and randomized clinical trial. J Endod 2013;39:173-176.

21. Wang C, Xu P, Ren L, Dong G, Ye L. Comparison of postobturation pain experience following one-visit and two-visit root canal treatment on teeth with vital pulps: a randomized controlled trial. Int Endod J 2010;43:692-697.

22. Siqueira JF, Rocas IN, Fvieri A, Machado AG, Gahyva SM, Oliveira JC, Abad EC. Incidence of postoperative pain after intracanal procedures based on antimicrobial strategy. J Endod 2002;28:457-458.

23. Mor C, Rotstein I, Friedman S. Incidence of interappointment emergency associated with endodontic therapy. J Endod 1992;18:509-511.

24. Arslan H, Güven Y, Karataş E, Doğanay E. Effect of the Simultaneous Working Length Control during Root Canal Preparation on Postoperative Pain. J Endod 2017;43:1422-1427. 
25. Azim AA, Azim KA, Abbott PV. Prevalence of inter-appointment endodontic flare-ups and host-related factors. Clin Oral Investig 2017;21:889-894.

26. Kherlakian D, Cunha RS, Ehrhardt IC, Zuolo ML, Kishen A, da Silveira Bueno CE. Comparison of the Incidence of Postoperative Pain after Using 2 Reciprocating Systems and a Continuous Rotary System: A Prospective Randomized Clinical Trial. J Endod 2016;42:171-176.

27. Gambarini G, Testarelli L, De Luca M, Milana V, Plotino G, Grande NM, Rubini AG, Al Sudani D,
Sannino G. The influence of three different instrumentation techniques on the incidence of postoperative pain after endodontic treatment. Ann Stomatol 2013;20:152-155.

28. Relvas JB, Bastos MM, Marques AA, Garrido AD, Sponchiado EC Jr. Assessment of postoperative pain after reciprocating or rotary NiTi instrumentation of root canals: a randomized, controlled clinical trial. Clin Oral Investig 2016;20:1987-1993. 